\title{
ISOLATION OF POTENTIAL ANTIMICROBIAL METABOLITE FROM ENDOPHYTIC BACILLUS AMYLOLIQUEFACIENS DL06 OF CARNIVOROUS PLANT DROSERA BURMANNII VAHL.
}

\author{
MADHUBANTI CHAUDHURI ${ }^{1}$, PAUL AK ${ }^{1}$, ARUNDHATI PAL ${ }^{2 *}$ \\ ${ }^{1}$ Microbiology Laboratory, Department of Botany, University of Calcutta, Kolkata, West Bengal, India. ${ }^{2}$ Post Graduate, Department of \\ Botany, Serampore College, Hooghly, West Bengal, India. Email: arundhatipalcu@gmail.com
}

Received: 06 November 2020, Revised and Accepted: 24 December 2020

\section{ABSTRACT}

Objectives: Exploitation of bacterial endophytes for production of antimicrobial substances has led to the discovery of novel natural metabolites of diverse chemical nature. The present study focuses attention toward optimization of cultural conditions for production of antimicrobial compound(s) by an endophytic bacterium DL06 followed by its extraction and partial purification.

Methods: The leaf endophytic bacterium Bacillus amyloliquefaciens DL06 (GenBank Accession no. MK696415, Microbial Culture Collection Accession no. 4186) isolated from carnivorous plant Drosera burmannii has been identified as a potent producer of antimicrobial metabolite following agar cup assay against several test bacterial and fungal strains. Cultural conditions for production of antimicrobials were optimized by "one variable at a time" method. The active fraction was isolated and purified partially using solvent extraction, thin-layer chromatography, and high performance liquid chromatography (HPLC) analysis.

Results: B. amyloliquefaciens DL06 produced maximum antimicrobial compound in tryptic soy broth and Davis-Mingioli's medium when grown under shake culture. Production of the antimicrobial metabolite has been optimized for the inoculum density, aeration, temperature, $\mathrm{pH}$ as well as carbon, and nitrogen sources. The antimicrobial metabolite was extracted from the cell-free culture filtrate in butanol and partially purified by silica gel column chromatography and HPLC.

Conclusions: The antimicrobial metabolite, tentatively identified as quercetin showed broad spectrum bioactivity affecting several fungi and a number of Gram-positive and Gram-negative bacteria.

Keywords: Carnivorous plant, Drosera burmannii, Bacterial endophytes, Antimicrobial metabolite, Bacillus amyloliquefaciens.

(C) 2021 The Authors. Published by Innovare Academic Sciences Pvt Ltd. This is an open access article under the CC BY license (http://creativecommons.org/ licenses/by/4.0/) DOI: http://dx.doi.org/10.22159/ajpcr.2021v14i1.40187. Journal homepage: https://innovareacademics.in/journals/index.php/ajpcr

\section{INTRODUCTION}

The search for new and effective antibiotics and chemotherapeutic agents has prompted over the last few decades due to the development of multidrug resistance in human pathogenic microorganisms. Moreover, due to a number of environmental issues, the use of synthetic chemicals demands their replacement by natural substances, particularly from microbial sources as an alternative to control human and plant pathogens [1].

The enormous diversity of microorganisms harnessed from wide range of ecological niches has long been utilized by the mankind for the production of huge number of pharmaceuticals including antimicrobial substances [2]. Endophytic microorganisms residing inside the plants without producing any visible damage to the host plant are relatively under explored microbial population [3]. These hidden microbial communities have received substantial attention in recent years for their ability to produce novel bioactive secondary metabolites which are of special importance not only for the benefit of host plant but also for human beings as successful source of drugs. Functional metabolites produced by the endophytic microbes have a great potential for application in agricultural, food, pharmaceutical, and biotechnological industries $[1,4]$. Although many of these endophytic natural products have been demonstrated to exert antioxidant, antidiabetic, and immunosuppressive effects, a significant portion of them was established as antimicrobials [1,5-8].

Carnivorous plants show unique trapping organs for insect prey digestion and nutrient uptake. They have attracted the attention of the scientific community in the recent past because of distinctive plant metabolites and novel products. Species of Nepenthes and Drosera have been reported to be used traditionally in India and Southeast Asian countries for their therapeutic activity in treatment of gastrointestinal and lung ailments $[9,10]$. Moreover, Buch et al. $[11]$ have demonstrated antibacterial activity in the digestive fluid of Nepenthes spp. as well as from the fungal endophytes isolated from the fluid. Likewise, the endophytic fungi from Nepenthes ampullaria and Nepenthes mirabilis showed inhibition against a number of bacterial and fungal species $[12,13]$. However, the potentials of endophytic bacteria of carnivorous plants for production of antimicrobial metabolites have not been explored adequately and deserve due attention.

We have made preliminary investigations on the bioactive potentials of bacterial endophytes of Drosera burmannii $[14,15]$. In the present study, an attempt has been made to evaluate the production of antimicrobial metabolite by Bacillus amyloliquefaciens, a leaf endophyte of $D$. burmannii, and assess the in vitro efficacy of the metabolite against selected bacterial and fungal test strains.

\section{METHODS}

\section{Source and maintenance of bacterial cultures}

The bacterium Bacillus DL06, a leaf endophyte of carnivorous plant D. burmannii Vahl., was isolated previously [15] and used throughout this study. The bacterium was maintained on slopes of nutrient agar by repeated sub-culturing.

The test organisms used for assessment of antimicrobial activity include Acinetobacter baumannii MTCC 1425, Bacillus cereus MTCC 1272, Bacillus subtilis MTCC 441, Escherichia coli MTCC 1687, Klebsiella 
pneumoniae MTCC 530, Proteus vulgaris MTCC 426, Pseudomonas aeruginosa MTCC 1638, Pseudomonas cepacia MTCC 4684, Salmonella typhimurium MTCC 3224, Staphylococcus aureus MTCC 2943, Staphylococcus epidermidis MTCC 3383, Staphylococcus haemolyticus MTCC 435, Vibrio cholerae 0139; Alternaria solani MTCC 2101, Aspergillus niger MTCC 281, Curvularia lunata MTCC 2030, Fusarium oxysporum MTCC 1755, Penicillium citrinum MTCC 1256, Rhizoctonia solani MTCC 4633, Saccharomyces cerevisiae MTCC 170, Saccharomyces boulardii CNCM I-745, Sclerotium rolfsii, and Trichoderma viride. While the bacterial and fungal cultures were maintained on nutrient agar and Czapek Dox agar, respectively, yeast extract peptone dextrose agar was used for Saccharomyces only.

\section{Characterization and identification of the endophytic bacterial isolate}

The bacterium DL06 was characterized morphologically and physiobiochemically according to standard microbiological methods [16]. Exponentially growing bacterial cells in nutrient broth was used for scanning electron microscopy (Carl Zeiss Zeiss Evo 18). Antibiotic sensitivity pattern was determined following the Kirby-Bauer disc diffusion method [17]. The diameter of inhibition zones was measured to the nearest $\mathrm{mm}$ and the organism was categorized as resistant, intermediate, and sensitive following DIFCO Manual $10^{\text {th }}$ edition [18].

The 16S rRNA gene sequence analysis was carried out using two universal primer sets 8F (5'-AGAGTTTGATCCTGGCTCAG-3') and 1492R (5'-CGGTTACCTTGTTACGACTT-3'). Consensus sequence of 16S rDNA was generated and compared with closely related neighbor sequences retrieved from the NCBI database using BLAST search. Phylogenetic analysis was performed using the software package MEGA 6.0 after obtaining multiple alignments of the data available from the public databases by Thompson et al. [19].

\section{Time-course of growth and production of antimicrobials}

Erlenmeyer flasks $(250 \mathrm{ml})$ containing $50 \mathrm{ml}$ of mineral salts medium were inoculated with overnight grown culture and incubated at $32^{\circ} \mathrm{C}$ under continuous shaking $(120 \mathrm{rpm})$ for $144 \mathrm{~h}$. Samples were withdrawn at regular interval for determination of growth and antimicrobial activity. Growth was measured by estimating the cell dry weight and expressed as g/L. Antimicrobial activity of the cellfree culture filtrate was assessed by agar cup assay following passage through membrane filter $(0.2 \mu \mathrm{m})$ and freshly grown cultures of $E$. coli and $A$. niger were used as test organisms.

Determination of optimum conditions for production of antimicrobial metabolites

To determine the optimum conditions for production of antimicrobial metabolite, one variable at a time method was used and variations were made in the composition of growth media, inoculum density, aeration, temperature, $\mathrm{pH}$, carbon, and nitrogen sources. Growth and antimicrobial activity were assessed following the method described above.

Isolation and partial purification of the antimicrobials

The bacterium was grown in mineral salts medium under optimized cultural conditions. The antimicrobial metabolite was obtained from the cell-free culture filtrate following solvent extraction procedure using petroleum ether, benzene, diethyl ether, dichloromethane, ethyl acetate, dimethyl sulfoxide, chloroform, and butanol. Individual solvent fractions were evaporated to dryness under reduced pressure, dissolved in sterile distilled water, and assayed for antimicrobial activity by agar cup assay. Preparative thin-layer chromatography (TLC) of the active solvent fraction was performed using a number of solvent systems, spots were detected under ultraviolet light, and bioactivity was assayed as described above.

Butanol extraction was carried out from $1 \mathrm{~L}$ of cell-free culture filtrate and concentrated to $30 \mathrm{ml}$. For column chromatography, the concentrated butanol fraction $(30 \mathrm{ml})$ was loaded in a silica gel column (mesh size 60-120, $20 \mathrm{~mm} \times 350 \mathrm{~mm}$ ) pre-equilibrated with chloroform:methanol (1:3) mixture. The metabolites were eluted with chloroform:methanol (1:3) as the solvent system at a flow rate of $1 \mathrm{ml} / \mathrm{min}$ and fractions of $5 \mathrm{ml}$ each were collected. Individual fractions were assayed for antimicrobial activity following evaporation and dissolution in sterile distilled water.

The pooled active fractions obtained from the silica gel column were evaporated to dryness, dissolved in $2 \mathrm{ml}$ sterile distilled water, and subjected to high performance liquid chromatography (HPLC) using Agilent1290 Infinity II with pump model G1328 C and detector model G $7115 \mathrm{~A}$. The C18 column $(4.6 \mathrm{~mm} \times 250 \mathrm{~mm})$ was used and peaks were detected at $280 \mathrm{~nm}$. Phosphoric acid $(0.5 \%)$ and methanol $(90 \%)$ were used as mobile phases for gradient run of $15 \mathrm{~min}$ at a flow rate of $2 \mathrm{ml} / \mathrm{min}$ and injection volume of $100 \mu \mathrm{l}$. The fractions were collected with Agilent Infinity II Open LAB Chemstation Workstation model M830IAA and checked for antimicrobial activity following the usual agar cup assay.

\section{RESULTS}

\section{Characterization and identification of isolate DL06}

The endophytic isolate DL06 formed rough, white colonies on nutrient agar. Bacterium DL06 is Gram-positive, aerobic, motile rod (Fig. 1), forming endospores, and produced intra- and extracellular enzymes such as catalase, oxidase, amylase, nitrate reductase, pectinase, and protease. The optimum temperature and $\mathrm{pH}$ for growth were $32^{\circ} \mathrm{C}$ and 7 , respectively. It tolerates a maximum concentration of $3 \% \mathrm{NaCl}$. The isolate could utilize as well as ferment a number of carbon sources. It showed resistance to polymyxin $\mathrm{B}$, vancomycin, and chloramphenicol but was sensitive to erythromycin, ampicillin, ciprofloxacin, rifampicin, gentamycin, trimethoprim, tetracycline, chlortetracycline, novobiocin, and norfloxacin (Table 1). These morphological and physio-biochemical features of the isolate DL06 were compared with the standard descriptions available in the Bergey's Manual of Determinative Bacteriology [20] and was assigned to the genus Bacillus.

The nucleotide sequence of the 16SrRNAgene (1456 bp) of the bacterium DL06 was found to have $99 \%$ similarity with B. amyloliquefaciens and designated as $B$. amyloliquefaciens DL06. The nucleotide sequence of 16S rRNA gene of the strain DL06 has been submitted to the GenBank database of NCBI with an accession number of MK 696415 and the live culture has been deposited to the Microbial Culture Collection (MCC) and National Centre for Microbial Resource, Pune, India, under the accession number MCC 4186 (Fig. 2).

Time-course of growth and production of antimicrobials The growth-associated production of antimicrobial metabolite from B. amyloliquefaciens DL06 was evaluated by growing bacterium in

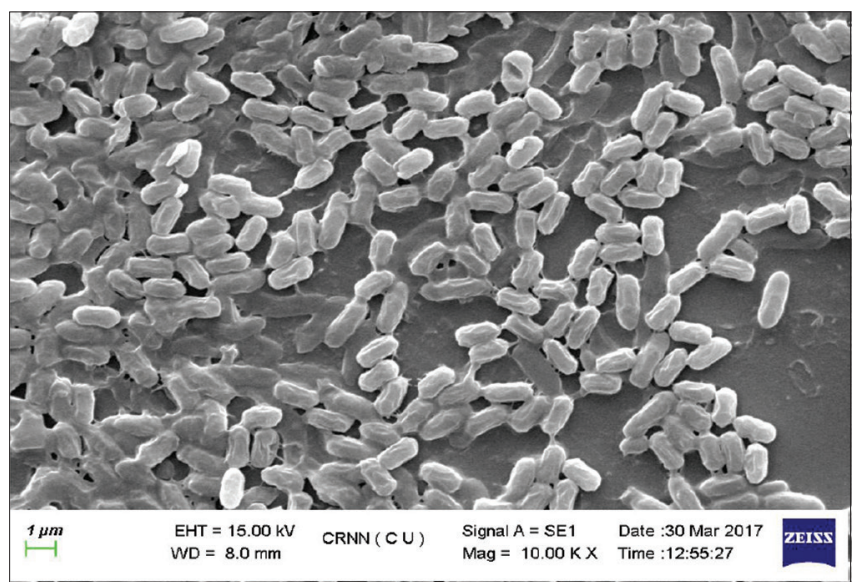

Fig. 1: Scanning electron micrograph showing morphology of cells of bacterial isolate DL06 
Table 1: Morphological and physio-biochemical characteristics of the endophytic bacterial isolate DL06

\begin{tabular}{|c|c|c|c|c|}
\hline \multirow{2}{*}{$\begin{array}{l}\text { Character } \\
\text { Colony }\end{array}$} & \multirow{2}{*}{$\begin{array}{l}\text { Response } \\
\text { Rough, white }\end{array}$} & \multirow{2}{*}{$\begin{array}{l}\text { Character } \\
\text { Fermentation and utilization of }\end{array}$} & \multicolumn{2}{|l|}{ Response } \\
\hline & & & Fermentation & Utilization \\
\hline Cell & Rods, $2.5-3 \mu \mathrm{m} \times 1.2-1.6 \mu \mathrm{m}$ & Glucose & + & + \\
\hline Gram nature & Gram +ve & Maltose & - & + \\
\hline Motility & + & Sucrose & - & + \\
\hline Endospore formation & + , central & Mannitol & + & + \\
\hline Production of catalase & + & Sorbitol & + & + \\
\hline Caseinase & + & Fructose & + & + \\
\hline Amylase & + & Lactose & + & - \\
\hline Gelatinase & + & Rhamnose & - & - \\
\hline Pectinase & + & Raffinose & - & + \\
\hline Urease & - & Arabinose & + & + \\
\hline Nitrate reductase & + & Aldonitol & - & - \\
\hline Cellulase & - & Dulcitol & - & - \\
\hline Lipase & - & Trehalose & - & + \\
\hline Indole production & - & Inositol & - & - \\
\hline Optimum growth $\mathrm{pH}$ & 7 & Antibiotic susceptibility & \multirow{2}{*}{\multicolumn{2}{|c|}{$\begin{array}{l}\mathrm{Pb}^{\mathrm{r}}, \mathrm{C}^{\mathrm{r}}, \mathrm{E}^{\mathrm{s}}, \mathrm{Amp}^{\mathrm{s}}, \mathrm{Cip}^{\mathrm{s}}, \mathrm{Rif}^{\mathrm{s}}, \mathrm{Gen}^{\mathrm{s}}, \\
\mathrm{Tri}^{\mathrm{s}}, \mathrm{Van}^{\mathrm{r}}, \mathrm{Tet}^{\mathrm{s}}, \mathrm{Ct}^{\mathrm{s}}, \mathrm{Nov}^{\mathrm{s}}, \text { Nor }^{\mathrm{s}}\end{array}$}} \\
\hline Maximum $\mathrm{NaCl} \%$ tolerance & $3 \%$ & & & \\
\hline
\end{tabular}

Antibiotics: E: Erythromycin, Pen: Penicillin G, C: Chloramphenicol, Amp: Ampicillin, Cip: Ciprofloxacin, Rif: Rifampicin, Gen: Gentamycin, Tri: Trimethoprim, Van: Vancomycin, Tet: Tetracycline, Ct: Chlortetracycline, Nov: Novobiocin, Nor: Norfloxacin, s: Sensitive, r: Resistant, + indicates positive response, - indicates negative response

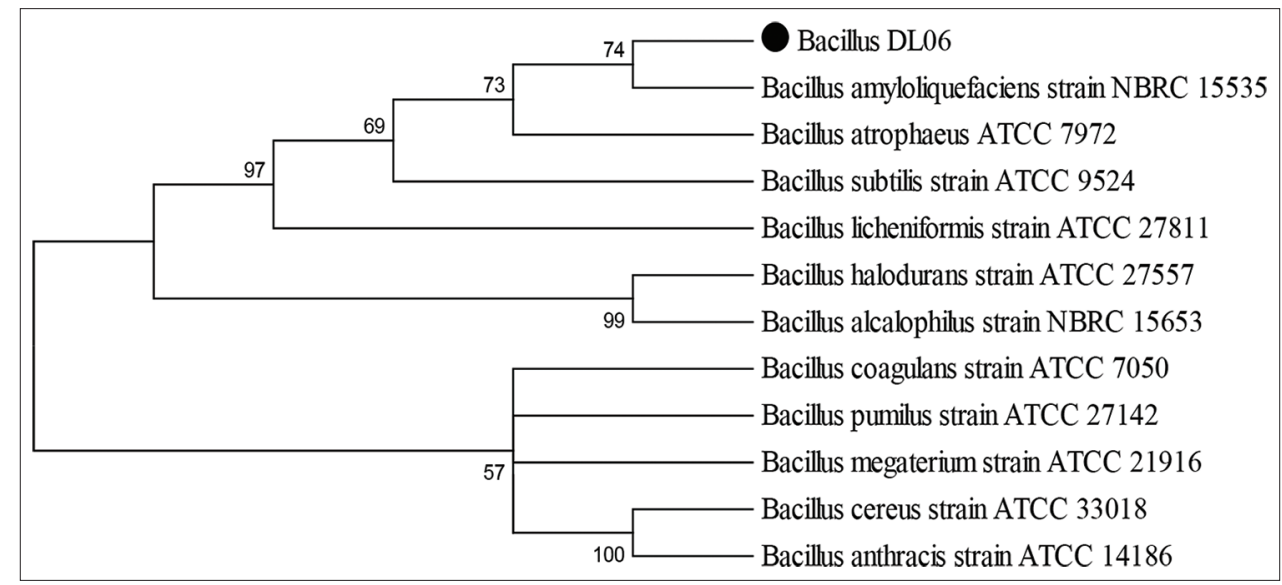

Fig. 2: Phylogenetic relationship of the endophytic bacterial isolate DL06 with other closely related species based on 16S rRNA gene sequence analysis

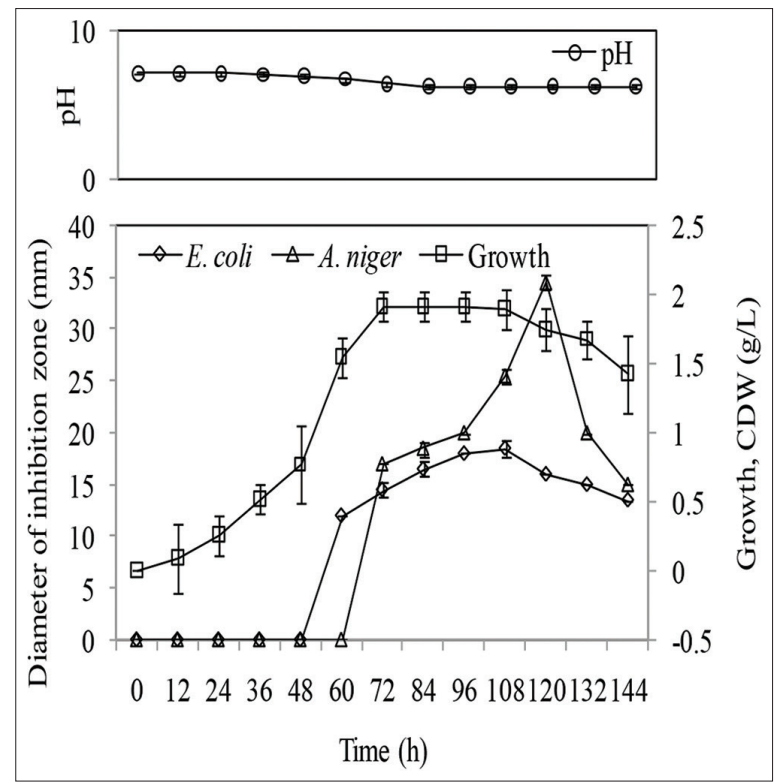

Fig. 3: Time course of growth and production of antimicrobia metabolite by Bacillus amyloliquefaciens DL06 mineral salts medium under shake-flask culture and bioactivity was assessed following agar cup assay against $E$. coli and A. niger. Production of antimicrobial metabolite was found to initiate during the active phase of growth which attained its highest titer (diameter of inhibition zone $33 \mathrm{~mm}$ against $A$. niger) during the late stationary phase (120 h) (Fig. 3).

\section{Spectrum of bioactivity of B. amyloliquefaciens DL06}

The cell-free culture filtrate from B. amyloliquefaciens DL06 was evaluated for antimicrobial spectrum determination following agar cup assay using test bacterial and fungal strains (Table 2). The metabolite showed broad spectrum of activity affecting $B$. cereus, $S$. haemolyticus, $S$. epidermidis, P. aeruginosa, and K. pneumoniae among the bacteria and A. solani, C. lunata, S. rolfsii, R. solani, F. oxysporum, T. viride, and $S$. boulardii among the fungi.

\section{Optimization of cultural conditions}

During the present study, a number of cultural conditions affecting growth and production of antimicrobial metabolites were optimized using one variable at a time. The variables include culture media of different composition, inoculum density, aeration, temperature, $\mathrm{pH}$, carbon, and nitrogen sources. Among different complex and synthetic media tested, bioactivity against $A$. niger was found to be high in tryptic soy broth and Davis-Mingioli's medium followed by mineral salts medium (MSM), Straw infusion medium (SI), and Gause's synthetic medium (GSM) (Fig. 4). 


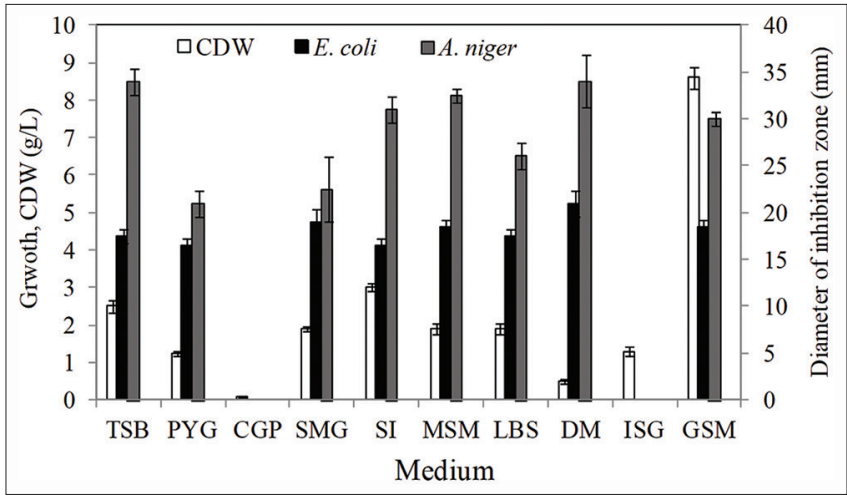

Fig. 4: Effect of different culture media on growth and production of antimicrobial metabolite by Bacillus amyloliquefaciens DL06. TSB: Tryptic soy broth, PYG: Peptone yeast extract glucose broth, CGP: Casamino acid glucose peptone broth, SMG: Soybean meal glucose medium, SI: Straw infusion medium, MSM: Mineral salts medium, LBS: Lindenbein synthetic medium, DM: Davis-Mingioli's medium, ISG: Inorganic salt glucose medium, GSM: Gause's synthetic medium

Table 2: Antimicrobial spectrum of the cell-free culture filtrate of Bacillus amyloliquefaciens DL06

\begin{tabular}{|c|c|}
\hline Test organism & $\begin{array}{l}\text { Diameter of inhibition } \\
\text { zone }(\mathrm{mm})\end{array}$ \\
\hline \multicolumn{2}{|l|}{ Bacteria } \\
\hline Acinetobacter baumannii MTCC 1425 & NI \\
\hline Bacillus cereus MTCC 1272 & $14.5 \pm 0.71$ \\
\hline Bacillus subtilis MTCC 441 & $14.0 \pm 1.41$ \\
\hline Burkholderia cepacia MTCC 4684 & $\mathrm{NI}$ \\
\hline Escherichia coli MTCC 1687 & $17.5 \pm 0.71$ \\
\hline Klebsiella pneumoniae MTCC 530 & $12.5 \pm 0.71$ \\
\hline Proteus vulgaris MTCC 426 & $\mathrm{NI}$ \\
\hline Pseudomonas aeruginosa MTCC 1688 & $14.5 \pm 0.71$ \\
\hline Salmonella typhimurium MTTC 3224 & $\mathrm{NI}$ \\
\hline Staphylococcus aureus MTCC 2943 & $13.0 \pm 2.82$ \\
\hline Staphylococcus epidermidis MTCC 3383 & $14.5 \pm 0.52$ \\
\hline Staphylococcus haemolyticus MTCC 435 & $13.5 \pm 0.55$ \\
\hline Vibrio cholerae 0139 & $\mathrm{NI}$ \\
\hline \multicolumn{2}{|l|}{ Fungi } \\
\hline Alternaria solani MTCC 2101 & $31.5 \pm 0.55$ \\
\hline Aspergillus niger MTCC 281 & $32.5 \pm 0.71$ \\
\hline Curvularia lunata MTCC 2030 & $32.5 \pm 0.71$ \\
\hline Fusarium oxysporum MTCC 1755 & $15.5 \pm 0.71$ \\
\hline Penicillium citrinum MTCC 1256 & $\mathrm{NI}$ \\
\hline Rhizoctonia solani MTCC 4633 & $24.5 \pm 0.71$ \\
\hline Saccharomyces boulardii CNCM I-745 & $10.5 \pm 0.52$ \\
\hline Saccharomyces cerevisiae MTCC 170 & $24.0 \pm 1.41$ \\
\hline Sclerotium rolfsii & $20.0 \pm 0.71$ \\
\hline Trichoderma viride & $22.5 \pm 0.52$ \\
\hline
\end{tabular}

${ }^{a}$ Antimicrobial activity was determined following standard agar cup assay method. NI: No inhibition, Values represent mean of triplicates \pm standard deviation
Maximum growth and production of antimicrobial metabolite occurred at an inoculum dose of $1.5 \%(\mathrm{v} / \mathrm{v})$ and at culture volume:flask volume ratio (CVF) of 1:5. The optimum temperature and $\mathrm{pH}$ for antimicrobial activity were recorded at $32^{\circ} \mathrm{C}$ and 6.6 , respectively. Among the 12 different carbon sources tested, glucose at a concentration of $2.2 \%(\mathrm{w} / \mathrm{v})$ was found to be most effective for production of antimicrobial metabolite. Likewise, tryptone was the best utilized nitrogen source for bioactivity and maximum growth as well as antimicrobial activity was observed at a concentration of $1.2 \mathrm{~g} / \mathrm{L}$ (Table 3)

Isolation and partial purification of the antimicrobials

The antimicrobial metabolites produced by B. amyloliquefaciens DL06 in mineral salts medium was extracted from the cell-free culture filtrate using a number of solvents. The antimicrobial metabolite was best extracted in butanol; however, dichloromethane and ethyl acetate as extractants were not that efficient (Table 4).

The butanolic extract when subjected to TLC using a number of solvent systems, maximum number of spots was detected in the chloroform:methanol (1:3) mixture. Preparative TLC revealed that the third spot $\left(\mathrm{C}_{3}\right)$ with $\mathrm{R}_{\mathrm{f}}$ value of 0.84 was having bioactivity. The second spot $\left(\mathrm{C}_{2}\right)$ with more or less identical $\mathrm{R}_{\mathrm{f}}$ value $(0.87)$ as detected in ethanol:water:chloroform $(4: 4: 2)$ mixture also showed a comparatively lesser degree of inhibition (Table 5).

Further, the concentrated butanolic extract of the cell-free culture filtrate was subjected to column chromatography (silica gel, 60-120 mesh size) using chloroform:methanol (1:3) mixture as the solvent system. Fractions, $5 \mathrm{ml}$ each were collected, evaporated to dryness and assayed for antimicrobial activity after dissolving in sterile water.

Bioactivity obtained in fractions 7 and 8 were pooled and subjected to HPLC (Agilent1290 Infinity II) analysis. Six distinct peaks with retention time were visualized in the chromatogram (Fig. 5). The compound with retention time 12.5 min showing antimicrobial activity against $E$. coli and $A$. niger was tentatively identified as quercetin.

\section{DISCUSSION}

The increasing demand for discovery of new antimicrobials has led the scientific community to explore the vast diversity of endophytic microorganisms in plants as potential bioresource for bioactive metabolites [1]. Several studies have reported the isolation of large number of chemically diverse group of antimicrobials from endophytes of different plant sources [13,21-23].

Association of microbial communities in the internal environment of carnivorous or insectivorous plants has received attention only in the last few decades. Both culture dependent and culture independent studies have established the occurrence of endophytic bacteria and fungi in these spectacular plants [24-28]. While preliminary reports

Table 3: Optimization of cultural conditions for growth and production of antimicrobial metabolite by Bacillus amyloliquefaciens DL06

\begin{tabular}{|c|c|c|c|c|c|}
\hline \multirow[t]{3}{*}{ Parameter } & \multirow[t]{3}{*}{ Test range } & \multirow{3}{*}{$\begin{array}{l}\text { Optimum } \\
\text { condition }\end{array}$} & \multirow{3}{*}{$\begin{array}{l}\text { Growth, } \\
\text { CDW (g/L) }\end{array}$} & \multicolumn{2}{|c|}{ Diameter of inhibition zone (mm) } \\
\hline & & & & \multicolumn{2}{|l|}{ Test organism } \\
\hline & & & & Escherichia coli & Aspergillus niger \\
\hline Inoculum dose $(\%, \mathrm{v} / \mathrm{v})$ & $0.5-2$ & 1.5 & $0.58 \pm 0.11$ & $21.5 \pm 0.71$ & $34.5 \pm 0.71$ \\
\hline Aeration (CVF) & $1: 10,1: 5,2: 5,3: 5,4: 5$ & $1: 5$ & $0.7 \pm 0.08$ & $21.5 \pm 0.71$ & $34 \pm 1.41$ \\
\hline Temperature $\left({ }^{\circ} \mathrm{C}\right)$ & $28-42$ & 32 & $0.75 \pm 0.11$ & $20.5 \pm 0.71$ & $34.5 \pm 0.71$ \\
\hline $\mathrm{pH}$ & $5-10.6$ & 6.6 & $0.81 \pm 0.08$ & $23.5 \pm 0.71$ & $34.5 \pm 0.71$ \\
\hline Carbon source & Glu, fru, gal, lac, mal, suc, mann, raff, sor, ara, ino, man & Glu & $0.5 \pm 0.11$ & $20.5 \pm 0.71$ & $34.5 \pm 0.71$ \\
\hline Glucose $(\%, \mathrm{w} / \mathrm{v})$ & $1.6-2.4$ & 2.2 & $0.56 \pm 0.02$ & $22.5 \pm 0.71$ & $35 \pm 1.41$ \\
\hline Nitrogen source & Pep, Tryp, Cas, YE, $\mathrm{NH}_{4} \mathrm{Cl},\left(\mathrm{NH}_{4}\right)_{2} \mathrm{SO}_{4}, \mathrm{NaNO}_{3}, \mathrm{NH}_{4} \mathrm{NO}_{3}$ & Tryp & $0.69 \pm 0.11$ & $21 \pm 1.41$ & $35 \pm 1.41$ \\
\hline Tryptone (g/L, w/v) & $0.6-1.4$ & 1.2 & $1.02 \pm 0.03$ & $22.5 \pm 0.71$ & $36.5 \pm 0.71$ \\
\hline
\end{tabular}

Values represent mean of triplicate experiments \pm standard deviation; CVF: Culture volume by flask volume ratio; glu - glucose, gal - galactose, suc - sucrose,

ara - arabinose, fru - fructose, tre - trehalose, sor - sorbitol, man - mannose, mann - mannitol; Pep - peptone, Cas - casamino acid, Tryp - tryptone, YE - Yeast extract 
on antimicrobial activities of fungal endophytes of $N$. mirabilis and $N$. ampullaris [12] and the bacterial endophytes of Drosera and Utricularia $[14,15]$ have recently been published, no in depth studies on their metabolites have been undertaken so far. The present study is based on the production, partial characterization, and optimization of antimicrobial metabolite from a leaf endophytic bacterium Bacillus DL06 from D. burmannii. The Gram-positive, endospore forming motile rod-shaped bacterium was identified as Bacillus amyloliquefaciens DL06 (GenBank Accession number MK696415; MCC Accession no. 4186) based on phenotypic features and 16S rRNA gene sequence

Table 4: Solvent extraction of antimicrobial substance produced by Bacillus amyloliquefaciens DL06 ${ }^{a}$

\begin{tabular}{lll}
\hline Solvent & \multicolumn{2}{l}{ Diameter of inhibition zone (mm) } \\
\cline { 2 - 3 } & \multicolumn{2}{l}{ Test organism } \\
\cline { 2 - 3 } & Escherichia coli & Aspergillus niger \\
\hline Petroleum ether & NI & NI \\
Benzene & NI & NI \\
Diethyl ether & NI & NI \\
Dichloromethane & $12.5 \pm 0.71$ & $14.5 \pm 0.71$ \\
Ethyl acetate & $14.5 \pm 2.82$ & $15.5 \pm 0.71$ \\
Dimethyl sulfoxide & NI & NI \\
Chloroform & NI & NI \\
Butanol & $21.5 \pm 0.71$ & $35.5 \pm 2.81$ \\
\hline
\end{tabular}

${ }^{\mathrm{a} A n t i m i c r o b i a l ~ m e t a b o l i t e ~ w a s ~ e x t r a c t e d ~ f r o m ~ t h e ~ c u l t u r e ~ f i l t r a t e ~ o f ~ t h e ~ i s o l a t e ~}$ after $120 \mathrm{~h}$ of growth and assayed against test organisms following agar cup method. NI: No inhibition, Values represent mean of triplicates \pm standard deviation analysis (Fig. 1 and 2 and Table 1). Occurrence of B. amyloliquefaciens as endophyte is not new and has already been reported from different plant sources (Table 6).

Cell-free culture filtrate of Bacillus DL06 was found to inhibit the growth of B. cereus, S. haemolyticus, S. epidermidis, P. aeruginosa, and K. pneumoniae among the bacteria tested and A. solani and C. lunatas among the fungi (Table 2). Comparison of antimicrobial activities of the present isolate DL06 with those of endophytic B. amyloliquefaciens reported previously [29-34] was carried out (Table 6). While the metabolites produced by B. amyloliquefaciens BZ6-1, Blu-v-2, August $\mathrm{M}-1, \mathrm{M}-2$, and Halycon 1 showed antifungal activities against variety of phytopathogens [29,30], B. amyloliquefaciens PEBA-20 endophytic to poplar exhibited both antifungal and antibacterial activities [31]. Leaf endophyte B. amyloliquefaciens HY-10 from Hyptis suaveolens demonstrated activity against clinical pathogens including Shigella dysenteriae and Candida spp. [32]. Bhoonobtong et al. [34] reported isolation and purification of antibacterial metabolites from B. amyloliquefaciens UD25 that inhibited several bacterial test strains including $S$. aureus (MRSA). A novel antimicrobial protein was reported from endophytic B. amyloliquefaciens that showed biocontrol of Fusarium chlamydosporum [35]. Recently, Wang and Wang [33] showed that resistance of sweet potato was elicited against two fungal pathogens due to in vitro occurrence of endophytic B. amyloliquefaciens YTB1407.

Time-course studies for growth and production of antimicrobial metabolite were carried out (Fig. 3). Suitable media for production of the metabolite by B. amyloliquefaciens DL06 (Fig. 4) and the optimum cultural conditions were determined (Table 3). The bioactive compound

Table 5: Preparative thin-layer chromatography of the butanol fraction of cell-free culture filtrate of Bacillus amyloliquefaciens DL06

\begin{tabular}{|c|c|c|c|c|}
\hline \multirow[t]{3}{*}{ Solvent system } & \multirow[t]{3}{*}{ No. of spots } & \multirow[t]{3}{*}{$\mathbf{R}_{\mathrm{f}}$ value } & \multicolumn{2}{|c|}{ Diameter of inhibition zone (mm) } \\
\hline & & & \multicolumn{2}{|l|}{ Test organism } \\
\hline & & & Escherichia coli & Aspergillus niger \\
\hline Ethanol:water:chloroform & $\mathrm{C}_{1}$ & 0.27 & $\mathrm{NI}$ & $\mathrm{NI}$ \\
\hline$(4: 4: 2)$ & $\mathrm{C}_{2}$ & 0.87 & $18.5 \pm 0.71$ & $30.5 \pm 0.71$ \\
\hline \multirow[t]{4}{*}{ Chloroform:methanol (1:3) } & $\mathrm{C}_{1}^{2}$ & 0.69 & $\mathrm{NI}$ & $\mathrm{NI}$ \\
\hline & $\mathrm{C}_{2}$ & 0.77 & NI & NI \\
\hline & $\mathrm{C}_{3}$ & 0.84 & $23.5 \pm 0.71$ & $36.5 \pm 0.71$ \\
\hline & $\mathrm{C}_{4}$ & 0.91 & $\mathrm{NI}$ & $\mathrm{NI}$ \\
\hline \multirow[t]{2}{*}{ Benzene:ethyl acetate (1:9) } & $\mathrm{C}_{1}^{4}$ & 0.25 & NI & $\mathrm{NI}$ \\
\hline & $\mathrm{C}_{2}$ & 0.34 & NI & $\mathrm{NI}$ \\
\hline
\end{tabular}

aIndividual spots were eluted and antimicrobial activity assayed against test organisms following agar cup method. NI: No inhibition, Values represent mean of triplicates \pm standard deviation

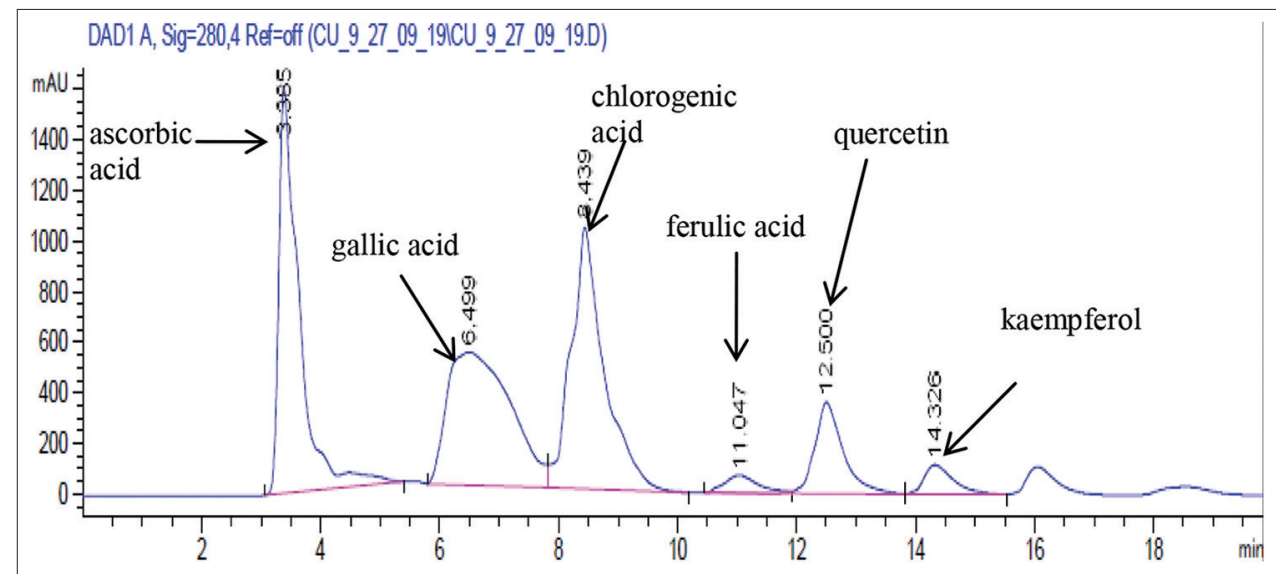

Fig. 5: High performance liquid chromatography chromatogram of the antimicrobial metabolites produced by Bacillus amyloliquefaciens DL06 
Table 6: Comparison of Bacillus amyloliquefaciens DL06 with other endophytic strains with respect to their source, antimicrobial metabolites, and activities

\begin{tabular}{|c|c|c|c|c|c|c|c|}
\hline \multirow{2}{*}{$\begin{array}{l}\text { Bacillus } \\
\text { amyloliquefaciens } \\
\text { strains }\end{array}$} & \multirow{2}{*}{$\begin{array}{l}\text { Source of } \\
\text { endophyte }\end{array}$} & \multirow{2}{*}{$\begin{array}{l}\text { Isolation } \\
\text { medium }\end{array}$} & \multicolumn{2}{|c|}{ Antimicrobial spectrum } & \multirow{2}{*}{$\begin{array}{l}\text { Test method } \\
\text { used }\end{array}$} & \multirow{2}{*}{$\begin{array}{l}\text { Metabolite } \\
\text { identified/ } \\
\text { chemical nature }\end{array}$} & \multirow[t]{2}{*}{ Reference } \\
\hline & & & Bacteria & Fungus & & & \\
\hline PEBA 20 & $\begin{array}{l}\text { Stem of Populus } \\
\text { tomentosa }\end{array}$ & $\begin{array}{l}\text { Nutrient } \\
\text { agar }\end{array}$ & $\begin{array}{l}\text { Bacillus subtilis, } \\
\text { Bacillus cereus, } \\
\text { Bacillus } \\
\text { megaterium }\end{array}$ & $\begin{array}{l}\text { Saccharomyces } \\
\text { cerevisiae, } \\
\text { Xanthomonas } \\
\text { campestris, Ralstonia } \\
\text { solanacearum, } \\
\text { Botryosphaeria } \\
\text { dothidea }\end{array}$ & $\begin{array}{l}\text { Disc diffusion } \\
\text { and agar-well } \\
\text { diffusion assay }\end{array}$ & NR & [31] \\
\hline BZ6-1 & Peanut stem & $\begin{array}{l}\text { Luria- } \\
\text { Bertani } \\
\text { agar }\end{array}$ & NR & $\begin{array}{l}\text { Ralstonia } \\
\text { solanacearum }\end{array}$ & $\begin{array}{l}\text { Agar-well } \\
\text { diffusion assay }\end{array}$ & $\begin{array}{l}\text { Homologue of } \\
\text { surfactin and } \\
\text { fengycin A }\end{array}$ & {$[30]$} \\
\hline UD25 & $\begin{array}{l}\text { Medicinal plant } \\
\text { Memecylon edule }\end{array}$ & $\begin{array}{l}\text { Nutrient } \\
\text { agar }\end{array}$ & $\begin{array}{l}\text { Staphylococcus } \\
\text { aureus (MRSA), } \\
\text { Pseudomonas } \\
\text { aeruginosa, Bacillus } \\
\text { cereus, Escherichia } \\
\text { coli }\end{array}$ & NR & $\begin{array}{l}\text { Agar-well } \\
\text { diffusion assay }\end{array}$ & $\begin{array}{l}\text { Presence of } \\
\text { carboxylic } \\
\text { acids, esters, } \\
\text { anthraquinone, } \\
\text { alkaloids, } \\
\text { carbonyl, thiol, } \\
\text { organohalogen }\end{array}$ & {$[34]$} \\
\hline $\begin{array}{l}\text { Blu-v2, August-M1, } \\
\text { August-M2, } \\
\text { Halycon1 }\end{array}$ & $\begin{array}{l}\text { Seed of } \\
\text { ornamental } \\
\text { plants }\end{array}$ & $\begin{array}{l}\text { Trypticase } \\
\text { soy agar }\end{array}$ & NR & $\begin{array}{l}\text { Alternaria } \\
\text { alternata, } \\
\text { Fusarium } \\
\text { oxysporum, } \\
\text { Colletotrichum } \\
\text { crassipes }\end{array}$ & $\begin{array}{l}\text { Cross-streak } \\
\text { method }\end{array}$ & $\begin{array}{l}\text { Isoforms of } \\
\text { surfactins, iturins, } \\
\text { and fengycins }\end{array}$ & [29] \\
\hline HY-10 & Hyptis suaveolens & $\begin{array}{l}\text { Nutrient } \\
\text { agar }\end{array}$ & $\begin{array}{l}\text { Escherichia coli, } \\
\text { Bacillus subtilis, } \\
\text { Staphylococcus } \\
\text { aureus, Shigella } \\
\text { dysenteriae }\end{array}$ & Candida spp. & $\begin{array}{l}\text { Disc diffusion } \\
\text { assay }\end{array}$ & $\begin{array}{l}\text { Absorbance at } 254 \\
\mathrm{~nm}\left(\chi_{\max }=1.541\right)\end{array}$ & {$[32]$} \\
\hline YTB1407 & Ipomoea batatas & NR & NR & $\begin{array}{l}\text { Fusarium solani, } \\
\text { Ceratocystis } \\
\text { fimbriata }\end{array}$ & $\begin{array}{l}\text { In vitro and } \\
\text { pot trial } \\
\text { assays }\end{array}$ & $\begin{array}{l}\text { Expression of SA- } \\
\text { responsive NPR } 1 \\
\text { and PR } 1 \text { genes in } \\
\text { the host }\end{array}$ & {$[33]$} \\
\hline DL06 & $\begin{array}{l}\text { Leaf of Drosera } \\
\text { burmannii }\end{array}$ & $\begin{array}{l}\text { Nutrient } \\
\text { agar }\end{array}$ & $\begin{array}{l}\text { B. subtilis, E. coli, } \\
\text { Staphylococcus } \\
\text { aureus, } \\
\text { Staphylococcus } \\
\text { haemolyticus, } \\
\text { Staphylococcus } \\
\text { epidermidis, } \\
\text { Pseudomonas } \\
\text { aeruginosa, } \\
\text { Klebsiella } \\
\text { pneumoniae }\end{array}$ & $\begin{array}{l}\text { Aspergillus niger, } \\
\text { Saccharomyces } \\
\text { cerevisiae, Alternaria } \\
\text { solani, Sclerotium } \\
\text { rolfsii, Rhizoctonia } \\
\text { solani, Curvularia } \\
\text { lunata, Fusarium } \\
\text { oxysporum }\end{array}$ & $\begin{array}{l}\text { Agar cup } \\
\text { diffusion assay }\end{array}$ & $\begin{array}{l}\text { Tentatively } \\
\text { quercetin }\end{array}$ & $\begin{array}{l}\text { Present } \\
\text { study }\end{array}$ \\
\hline
\end{tabular}

NR: Not reported

was extracted in butanol (Table 4), preparative TLC was performed (Table 5) followed by HPLC analysis (Fig. 5), and the active fraction was determined tentatively as quercetin. The plant flavonol quercetin belongs to the flavonoid group of polyphenols. Inhibitory action of quercetin has been observed against $S$. aureus, P. aeruginosa, $P$. vulgaris, and E. coli [36,37]. Quercetin also showed antifungal effects against Cryptococcus spp. and Candida spp. [38-40]. Several reports document the production of different flavonoids from microbial endophytes. Quercetin was detected in secondary metabolites of endophytic bacteria of Cosmos caudatus leaf which showed anticancer and antimicrobial properties [41]. Endophytic fungi from Pinus roxburghii produce flavonoids having antimicrobial properties [42]. Flavonoids having bioactive potentials were identified from endophytic fungi of the medicinal plant Tragia involucrata which included vanillin, quercetin, caffeic acid, and ferulic acid [43]. As of now, Lee et al. [12] have shown antimicrobial properties of the fungi endophytic to Nepenthes spp. It had inhibitory activities against Streptococcus pyogenes, Enterococcus faecalis, and Ganoderma boninense.

\section{CONCLUSIONS}

The present study reports on the production of antifungal and antibacterial compound by a leaf endophyte $B$. amyloliquefaciens isolated from the carnivorous plant D. burmannii Vahl. Production of antimicrobial compound by the endophytic bacterial isolate was further optimized. The antimicrobial compound was purified and chemical nature of the active fraction was tentatively determined as quercetin. The research deserves special attention for application of bacterial endophtes from carnivorous plants in the field of pharmaceutical biotechnology. 


\section{ACKNOWLEDGMENTS}

We express our sincere gratitude to Prof. G. G. Maiti, Department of Botany, University of Kalyani and Dr. D. Maity, Department of Botany, University of Calcutta, Kolkata, for collection and taxonomic identification of the plant material.

\section{AUTHORS' CONTRIBUTIONS}

This work was carried out in collaboration between all authors. Author MC performed the experiments and prepared the draft manuscript. Author AKP designed the experiments. Author AP managed the analyses of result and literature survey. AKP and AP prepared the final manuscript. All authors read and approved the final manuscript.

\section{CONFLICTS OF INTEREST}

The authors declare that there are no conflicts of interest.

\section{AUTHOR'S FUNDING}

Financial assistance to Madhubanti Chaudhuri from University Grants Commission, New Delhi, India, is duly acknowledged.

\section{REFERENCES}

1. Strobel G, Daisy B. Bioprospecting for microbial endophytes and their natural products. Microbiol Mol Biol Rev 2003;67:491-502.

2. Demain AL. Biology of antibiotic formation. In: Vandamme EJ, editor. Biotechnology of Industrial Antibiotics. New York: Marcel Dekker Inc.; 1984. p. 33-42.

3. Stone JK, Bacon CW, White JF. An overview of endophytic microbes: Endophytism defined. In: Bacon CW, White JF, editors. Microbial Endophytes/ New York: Marcel Dekker; 2009. p. 3-29.

4. Guteirrez RM, Gonzales AM, Ramirez AM. Compounds derived from endophytes: A review of phytochemistry and pharmacology. Curr Med Chem 2012;19:2992-3030.

5. Castillo UF, Strobel GA, Ford EJ, Hess WM, Porter H, Jensen HB, et al. Munumbicins, wide-spectrum antibiotics produced by Streptomyces NRRL 30562, endophytic on Kennedia nigriscans. Microbiology 2002; $148: 2675-85$

6. Xie J, Wu Y, Zhang T, Zhang M. New antimicrobial compounds produced by endophytic Penicillium janthinellum isolated from Panax notoginseng as potential inhibitors of Ftsz. Fitoterapia 2018;131:35-43.

7. Manganyi M, Regnier T, Tchatchouang CK, Bezuidenhout C. Antibacterial activity of endophytic fungi isolated from Sceletium tortuosum L. (Kougoed). Ann Microbiol 2019;69:659-63.

8. Jayatilake PL, Munasinghe H. Antimicrobial activity of cultivable endophytic and rhizospheric fungi associated with "Mile-a-Minute" Mikania cordata (Asteraceae). Biomed Res Int 2020;2020:5292571.

9. Sanusi SB, Abu Bakar MF, Mohamed M, Sabran SF, Mainasara MM. Ethnobotanical, phytochemical, and pharmacological properties of nepenthes species: A review. Asian J Pharm Clin Res 2017:10:16-9.

10. Madhavan V, Basnett $\mathrm{H}$, Gurudeva MR, Yoganarasimhan SN. Pharmacognostical evaluation of Drosera burmannii Vahl (Droseraceae). Indian J Tradit Knowl 2009;8:326-333.

11. Buch F, Rott M, Rottloff S, Paetz C, Hilke I, Raessler M, Mithofer A. Secreted pitfall-trap fluid of carnivorous Nepenthes plants is unsuitable for microbial growth. Ann Bot 2013;111:375-83.

12. Lee JM, Tan WS, Ting AS. Revealing the antimicrobial and enzymatic potentials of culturable fungal endophytes from tropical pitcher plants (Nepenthes spp.). Mycosphere 2014;5:364-77.

13. Christina A, Christapher V, Bhore SJ. Endophytic bacteria as a source of novel antibiotics: An overview. Pharmacogn Rev 2013;7:11-6.

14. Chaudhuri M, Pal A, Paul AK. Investigation of biochemical properties and biological activities of bacteria endogenous to carnivorous plant Drosera burmannii Vahl. Int J Adv Biotechnol Res 2015;6:278-89.

15. Chaudhuri M, Paul AK, Pal A. Isolation and assessment of metabolic potentials of bacteria endophytic to carnivorous plants Drosera burmannii and Utricularia spp. Biosci Biotech Res Asia 2019;16:731-41

16. Gerhardt P. Methods for General and Molecular Bacteriology. Washington, DC: American Society for Microbiology; 1994.

17. Bauer AW, Kirby WM, Sherris JC, Turck M. Antibiotic susceptibility testing by a standardized single disc method, Am J Clin Pathol
1966; $45: 493$.

18. Difco Manual. Dehydrated Culture Media and Reagents for Microbiology. 10 $0^{\text {th }}$ ed. Detroit, Michigan: Difco Laboratories; 1984.

19. Thompson JD, Higgins DG, Gibson TJ. CLUSTAL W: Improving the sensitivity of progressive multiple sequence alignment through sequence weighting, position-specific gap penalties and weight matrix choice. Nucleic Acid Res 1994;22:4673-80.

20. Buchanan RE, Gibbons NE. Bergey's Manual of Determinative Bacteriology. Baltimore: Williams and Wilkins; 1975.

21. Yu H, Zhang L, Li L, Zheng C, Guo L, Li W, et al. Recent developments and future prospects of antimicrobial metabolites produced by endophytes. Microbiol Res 2010;165:437-49.

22. Joseph B, Priya RM. Bioactive compounds from endophytes and their potential in pharmaceutical effect: A review. Am J Biochem Mol Biol 2011;1:291-309.

23. Ek-Ramos MJ, Gomez-Flores R, Orozco-Flores AA, RodríguezPadilla C, González-Ochoa G, Tamez-Guerra P. Bioactive products from plant-endophytic Gram-Positive bacteria. Front Microbiol 2019; $10: 463$.

24. Glenn A, Bodri MS. Fungal endophyte diversity in Sarracenia. PLoS One 2012;7:1-7.

25. Quillium RS, Jones DL. Evidence of host-specificity of culturable fungal root endophytes form the carnivorous plant Pinguicula vulgaris. Mycol Prog 2012;11:583-585.

26. Naseem F, Kayang H. Fungal endophytes associated with Nepenthes khasiana Hook. F., an endemic plant of Meghalaya, India. Int J Curr Res Life Sci 2018;7:1907-12.

27. White JF Jr., Torres MS, Sullivan RF, Jabbour RE, Chen Q, Tadych M, et al. Occurrence of Bacillus amyloliquefciens as a systemic endophyte of Vanilla orchids. Microsc Res Tech 2014:77:1-12.

28. Chen YT, Yuan Q, Shan LT, Lin MA, Cheng DQ, Li CY. Antitumor activity of bacterial exopolysaccharides from the endophyte Bacillus amyloliquefaciens sp. isolated from Ophiopogon japonicus. Oncol Lett 2013;5:1787-92

29. Li H, Soares MA, Torres MS, Bergen M, White JF Jr. Endophytic bacterium, Bacillus amyloliquefaciens, enhances ornamental host a resistance to diseases and insect pests. J Plant Interact 2015;10:224-9.

30. Wang X, Liang G. Control efficacy of an endophytic Bacillus amyloliquefaciens strain BZ6-1 against peanut bacterial wilt, Ralstonia solanacearum. Biomed Res Int 2014;2014:465435.

31. Yin X, Xu L, Xu L, Fan S, Liu Z, Zhang X. Evaluation of the efficacy of endophytic Bacillus amyloliquefaciens against Botryosphaeria dothidea and other phytopathogenic microorganisms. Afr J Microbiol Res 2011;5:340-5.

32. Das I, Panda M, Rath CC, Tayung K. Bioactivities of bacterial endophytes isolated from leaf tissues of Hyptis suaveolens against some clinically significant pathogens. J Appl Pharm Sci 2017;7:131-6.

33. Wang C, Wang Y. Endophytic Bacillus amyloliquefaciens YTB1407 elicits resistance against two fungal pathogens in sweet potato (Ipomoea batatas Lam.). J Plant Physiol 2020;253:154260.

34. Bhoonobtong A, Sodngan S, Boonlue S, Bunyatratchata W, Mongkoit W. Antibiotics constituents of endophytic Bacillus amyloliquefaciens UD25 extracted from a medicinal plant, Memecylon edule Roxb. Chiang Mai J Sci 2015;44:788-99.

35. Zhu H, Pan Y. A novel antimicrobial protein of the endophytic Bacillus amyloliquefaciens and its control effect against Fusarium chlamydosporum. Biocontrol 2019;64:737-48.

36. Woźnicka E, Kuźniar A, Nowak D, Nykiel E, Kopacz M, Gruszecka J, et al. Comparative study on the antibacterial activity of some flavonoids and their sulfonic derivatives. Acta Pol Pharm 2013;70:567-71.

37. Jaisinghani RN. Antibacterial properties of quercetin. Microbiol Res 2017;8:13-4

38. da Silva CR, Neto BA, Campos RS, Figueiredo NS, Sampaio LS, Magalhaes HI, et al. Synergistic effect of the flavonoid catechin, quercetin or epigallocatechin gallate with fluconazole induces apoptosis in Candida tropicalis resistant to fluconazole. Antimicrob Agents Chemother 204:58:1468-78.

39. De Oliveira MR, Nabavi SM, Braidy N, Setzer WN, Ahmed T, Nabavi SF. Quercetin and the mitochondria: A mechanistic view. Biotechnol Adv 2016;34:532-49.

40. Rocha MF, Sales JA, da Rocha MG, Galdino LM, de Aguiar L, et al. Antifungal effects of the flavonoids kaempferol and quercetin: A possible alternative for the control of fungal biofilms. Biofouling 2019;35:320-8.

41. Ramadhan F, Mukarramah L, Oktavia FA, Yulian R, Annisyah NH, 
Asyiah IS. Flavonoids from endophytic bacteria of Cosmos caudatas Kunth. leaf as anticancer and antimicrobial. Asian J Pharm Clin Res 2018;11:200-4.

42. Bhardwaj A, Sharma D, Jadon N, Agarwal PK. Antimicrobial and phytochemical screening of endophytic fungi isolated from spikes of
Pinus roxburghii. Arch Clin Microbiol 2015;6:1-9.

43. Danagoudar A, Joshi CG, Ravi SK, Kumar HG, Ramesh BN. Antioxidant and cytotoxic potential of endophytic fungi isolated from medicinal plant Tragia involucrata L. Pharmacogn Res 2018;10:188-94. 